\title{
Michel Wieviorka, Solidarność i antysemityzm
}

Niewielu socjologom polska humanistyka i polskie społeczeństwo zawdzięczają tak wiele, jak właśnie Michelowi Wieviorce. To właśnie z jego inicjatywy powstał zespół z Alainem Touraine'em, François Dubetem oraz Janem Strzeleckim, który przeprowadził interwencję socjologiczną w Polsce w 1981 roku. I choć na okładkach francuskiego (1982), brytyjskiego (1983) oraz polskiego $(1989,2010)$ wydania pracy Solidarność. Analiza ruchu społecznego 1980-1981 widnieje Alain Touraine jako wyróżniony autor i twórca zastosowanej wówczas metody badawczej - interwencji socjologicznej - to właśnie Wieviorka wyszedł ze śmiałą propozycją przeprowadzenia badania w Polsce i przygotowywał je wraz z Dubetem, przyjeżdżając po raz pierwszy do kraju w kwietniu 1981 roku.

Z trójki badaczy, którzy w 1981 roku utworzyli zespół Centrum Analizy i Interwencji Socjologicznej (CADIS) na prestiżowej École des hautes études en sciences sociales (EHESS) w Paryżu, to właśnie Michel Wieviorka jako jedyny powrócił w systematyczny sposób do pracy nad materiałem badawczym z interwencji socjologicznej dotyczącej Solidarności. W swojej monografii Żydzi, Polska i Solidarność (Les Juifs, la Pologne et Solidarność, Denoël, Paris 1984) podjął temat antysemityzmu w polskiej kulturze od XIX wieku do współczesności, obejmując wydarzenia roku 1968 oraz sam ruch Solidarności. Ten ostatni wątek koncentruje się na antysemickich i nacjonalistycznych motywach związanych z dyskursem tak zwanych "prawdziwych Polaków", które ujawniły się w ostatnich miesiącach 1981 roku podczas I Krajowego Zjazdu Delegatów NSZZ "Solidarność". Prezentowany poniżej wybór czterech z jedenastu rozdziałów monografii rzuca światło na przejawy antysemityzmu, które Michel Wieviorka zaobserwował między majem a listopadem 1981 roku, także jako świadek zjazdu w Hali Olivia w Gdańsku.

Warto wspomnieć, że jako jedyny ze wspomnianej grupy socjologów Wieviorka ma polsko-żydowskie korzenie - jego dziadek urodzony w Mińsku Mazowieckim oraz babka urodzona w Siedlcach zginęli w obozie w Auschwitz. Losy rodziny stały się motywem podejmowanym przez rodzeństwo Michela Wieviorki. Jego siostra Annette, wybitna historyczka francuska, zajmuje się historią Żydów w XX wieku, w tym szczególnie zagładą, i jest autorką wydanej w języku polskim pracy Czym było Auschwitz?

\section{JACEK KOŁTAN}

Europejskie Centrum Solidarności 
(2015). Sylvie - to zaangażowana politycznie wykładowczyni i psychiatra, brat Olivier zaś to historyk i wykładowca specjalizujący się w II wojnie światowej, w tym w historii francuskiego oporu.

Sam Michel Wieviorka swoje badania skoncentrował nie tylko na ruchach społecznych czy antysemityzmie, ale też na rozwoju demokracji, a przede wszystkim na terroryzmie, rasizmie, przemocy i różnicach kulturowych w wielonarodowych społeczeństwach. Był dyrektorem CADIS w latach 1993-2009, zastąpiwszy na tym stanowisku Alaina Touraine'a, w latach 2006-2010 pełnił zaś funkcję prezesa Międzynarodowego Stowarzyszenia Socjologicznego. W jego tekstach z lat osiemdziesiątych, również w publikacjach prasowych, Solidarność obecna była jako przykład wielkiego antytotalitarnego ruchu społecznego. Ciesząc się autorytetem francuskich elit intelektualnych, przyczynił się do poszerzenia wiedzy o Solidarności i rozwoju sytuacji politycznej Polski. Uczestniczył w protestach przeciwko wprowadzeniu stanu wojennego i współinicjował akcje na rzecz uwolnienia więźniów politycznych w Polsce.

Doświadczenia rodzinne, ale też najważniejsze dla jego dalszej drogi zawodowej doświadczenie badań nad ruchem społecznym Solidarność, skutkowały nie tylko szczególną wrażliwością na niebezpieczeństwa przemocy w świecie społecznym i polityce, ale również na problem sprawiedliwości, ludzkiej godności i uznania. Tematy te, kluczowe dla Solidarności, pomogły mu ostrzej dostrzec deficyty i zagrożenia epoki neoliberalnej lat osiemdziesiątych. Z pełną klarownością Wieviorka (i jego ówczesny zespół badawczy) mógł przekonać się również o definitywnym kresie realnego socjalizmu. Podczas gdy środowiska lewicowe we Francji wciąż wiązały z nim swoje polityczne nadzieje, a część $z$ nich legitymizowała użycie przemocy, Michel Wieviorka - jak sam wspomina - dzięki Solidarności wyprzedzał o dekadę przemiany w myśleniu o politycznej rzeczywistości.

Za zasługi dla Solidarności został uhonorowany Medalem Wdzięczności Europejskiego Centrum Solidarności. Jego wykład Nowe wyzwania dla demokracji, wygłoszony z tej okazji, został wydany w pracy Solidarność, demokracja, Europa (red. Basil Kerski, Jacek Kołtan, ECS, Gdańsk 2020).

Oprócz wspomnianej na początku wybitnej pracy badawczej dotyczącej Solidarności, wydanej nakładem ECS w 2010 roku, do istotnych w jego dorobku książek wydawanych $\mathrm{z}$ powodzeniem w międzynarodowych przekładach, należą: Sociétés et terrorisme (1988), L'espace du racisme (1991), La Violence (2004), La Différence. Identités culturelles: enjeux, débats et politiques (2005), Dziewięć wykładów z socjologii (2008, wyd. pol. 2011), Retour au sens: pour en finir avec le déclinisme (2015) czy też Pour une démocratie de combat (2020). 